\title{
A Review of Minimizing Delay in Construction Industries
}

\author{
Muhamad Azry Khoiry ${ }^{1,2^{*}}$, Suhaniya Kalaisilven ${ }^{3}$, and Azlina Abdullah ${ }^{3}$ \\ ${ }^{1}$ Programme of Civil Engineering, Faculty of Engineering \& Built Environment, Universiti \\ Kebangsaan Malaysia, 43650 Bangi, Malaysia \\ ${ }^{2}$ Smart and Sustainable Township Research Centre (SUTRA), Faculty of Engineering \& Built \\ Environment, Universiti Kebangsaan Malaysia, 43650 Bangi, Malaysia \\ ${ }^{3}$ School of Social, Development \& Environmental Studies, Faculty of Social Sciences \& Humanities, \\ Universiti Kebangsaan Malaysia, 43600 Bangi Selangor, Malaysia
}

\begin{abstract}
Construction is an important industry to determine the development of a country. However, this industry faced delay issues caused by various factors that affect proper construction project. Hence, minimizing delay in construction should be focused on overcoming the delay issue. Thus, the objective of this study is to critically review the main criteria of minimizing delay based on the most significant items that suggested in the previous journals. This paper reviewed 47 journals that studied the issues of delays in construction projects. Through this study, the authors have classified four main criteria for minimizing delays, which are; management, interpersonal, technical and technology. Management ensures the proper manage of time, financial and control system in construction to minimize delay. While, interpersonal promote a good relationship between construction parties, hire of competent and skilled labour and responsibility of the owner to avoiding delay. Besides, technical ensure the quality of project and technology could improve the productivity of construction based on fourth industrial revolution development in the construction field. Thus, this study contributes to construction parties able to focus on elements to overcome the delay issue in they faced and applied the ideas based on the element to minimize delay in the construction project.
\end{abstract}

\section{Introduction}

Delay in construction is one of the crucial issues in the construction sectors. Construction delay is a common issue that faced by many developing countries such as Asian, Middle East, South Africa and Europe. A delay in construction is one of the well-established studies, there are many researcher conduct studies on the issue [1-5]. The factors causing's delay in construction sectors were due to financial, improper planning and scheduling, inexperienced contractor and owner change order and design. Based on the statistic from Malaysian Ministry of Urban Wellbeing, Housing and Local Government until April 2018,

\footnotetext{
*Corresponding author: azrykhoiry@ukm.edu.my
} 
333 housing projects were delayed [6]. The studies on minimizing delay can help Malaysia construction sectors to understand how to minimize delays in order to reduce the number of housing delay. Thus, this study merely focused on minimizing delays in construction. In these studies, all the recommendation of minimizing delay explored and major significant method of minimizing delays in construction identified.

\section{Methodology}

The previous studies chosen in this review paper focused on various countries issue in construction sectors. Thus, the 143 ideas of minimizing delays from the previous studies were identified. The minimizing ideas were rearranged to get the 27 most common ideas suggested by previous studies. Thus, the items on minimized delay were categorized into four elements such as management, interpersonal, technical and technology. The items summarized and discoursed based on the most significant items in construction. The journals are referred from various publisher including Emerald Insight, Springer and Elsevier. There also the International Conference of engineering papers and other International Journals from various publications were reviewed for this review paper. The next section of this paper will critically discuss the minimizing criteria to overcome construction delay.

\section{Minimizing Delay in Construction Industries}

Construction is a risky business; it is a risk that owners and contractors faced that can affect construction time. The cost of a lost day on a construction project may be staggering [7]. However, delay in the construction project is the common issue due to various factors. The issue has been studied by researchers from various countries and minimizing delay has been suggested in studies. In studies on minimizing delay, researchers have recommended the new model and idea of improvement that can be done to reduce delay in the construction sector. The entire element plays important roles to help construction parties identify and focus on the issue they faced. Therefore, this paper discusses minimizing delay in construction from an idea of these criteria which are management, interpersonal, technical and technology.

\subsection{Management}

Construction project management are the planning, coordination and control on a project from conception to completion, including commissioning on behalf of a client requiring, the identification of the client's objectives in terms of utility, function, quality, time and cost, and the establishment of relationship between resources, integrating, monitoring and controlling the contributors to the project and their output, and evaluating and selecting alternatives in pursuit of the client's satisfaction with the project outcome [8].

Construction management also is the way; contributors are organized so that their skills are used in the right manner and at the right time to maximise benefits for the clients. The owner, contractor, and consultant are essential in a construction project. Therefore, ideas of minimizing delays in constructions are suggested based on owner, contractor and consultant perspective [9-11]. Based on Table 1, minimizing delay in management is divided into time, financial, manpower, work scope, and control. The details of each category are discussed in the next section. 
Table 1. Minimizing Delay Items under Management Category

\begin{tabular}{|c|c|}
\hline Categories & Items (Authors) \\
\hline \multirow{2}{*}{ Time } & Specification of a realistic duration to execute the project $[2,3,6,10]$. \\
\hline & Proper planning and scheduling $[3,5,8,10,13,14,17-24]$. \\
\hline \multirow[b]{2}{*}{ Control } & Obtaining the required approvals of the project from authorities $[2,5,17]$. \\
\hline & $\begin{array}{l}\text { Development of a good system for site management and supervision }[2,4,11 \text {, } \\
15,18,19,22-30] \text {. }\end{array}$ \\
\hline \multirow{3}{*}{ Administration } & $\begin{array}{l}\text { Construction management companies to help minimize delays or their } \\
\text { impacts }[5,9,14,30-32] \text {. }\end{array}$ \\
\hline & Joint efforts of participants in the construction $[9,11,14,33]$ \\
\hline & Site conditions have to be improved $[3,4,15,18]$ \\
\hline \multirow{3}{*}{ Financial } & $\begin{array}{l}\text { Payment to the contractor on time for the work being carried and finished } \\
\text { based on contract. }[2,12,14,15,19,20,27,34]\end{array}$ \\
\hline & Ensure adequate and available source of finance $[14,18,21]$ \\
\hline & $\begin{array}{l}\text { Improving cash flow \& plan the cash flow before start project }[18,24,28,31 \text {, } \\
39]\end{array}$ \\
\hline Manpower & $\begin{array}{l}\text { Employ employer based on their work/skills speciation in construction project } \\
{[3,38,18]}\end{array}$ \\
\hline Work scope & Work scope needs to be well defined $[4,18,31,38,40]$ \\
\hline \multirow[t]{2}{*}{ Design } & $\begin{array}{l}\text { Prepare always clear and adequate detail drawing and BOQ (Bill of quantity) } \\
\text { without any mistakes }[9,18,28]\end{array}$ \\
\hline & Accurate initial study and design $[13,14,36]$ \\
\hline
\end{tabular}

\subsubsection{Time}

Time is very important to minimize delays in the construction sector. This statement was supported and highlighted in 13 journals. A proper project planning and the scheduling are the essentials of an efficient time management. Thus, a realistic schedule ensures the site manager to be able to coordinate the labours into proper project constructions [3]. As management need to apply the technique to manage a construction project with proper planning, scheduling, financial charts, rules and regulation [9]. Furthermore, these project plan serves as a blueprint for the measurement of the work performed at different phases of the construction [11]. An effective planning phase has to planned detailed and carefully as losses in a construction project can be avoided [13, 20, 23]. Studies in Zambia recommended that the projects for construction should be pre-planned and timed as most of the works can be executed in seasons of clement weather [20]. The contractor has to plan and schedules the project beforehand as if an unexpected issue occurs, only well planned and a scheduled project can execute [22]. The planning phase should be planned carefully to avoid any loses and the requirement of the project is missed out $[22,24]$. It is important to a construction project pre-planned and the scheduled from the starting phase and strictly followed by construction parties to avoid delays in the project.

\subsubsection{Control}

Control in a construction project is important as the owner tend to control contractor via supervising and monitoring the construction work daily or weekly basis as agreed in the contract. At the same time, contractor controls their subcontractor in constructions to avoid delays. The controls among construction parties can be applied via proper site management and supervision as it was ranked the second methods of minimizing delay suggested. As someone, who invested money in project development, owners have major roles to monitor and supervise contractor and consultant to achieve the duration target to complete the construction. Thus, the client needs to conduct a weekly meeting or monitoring visit the 
contractors and consultants to updated with current work progress and issue [4, 21]. The frequent meeting with management to supervise construction activities in site [11] can help fasten the project construction according to the contract agreement. Moreover, the contractor also required to establish a good control system to manage and control the variation order from the owner to applied in construction project $[2,18]$. In other hands, a periodical report of monitoring and cause of delay during the work progress [2] by contractor help them to identified issues and avoid rework of projects. A specified management team has to be assigned to complete the construction project within the timeframe while maintaining the quality of the work accordingly [22]. Monitoring and supervise on work progress is important as owners and contractors able to identify the issues earlier and provide solutions to avoid time overrun in a construction project.

\subsubsection{Financial}

Financial management is important in construction as difficulties in financial causes project delays [41]. Delay can be minimized via timely payment to the contractor. The payment should be paid for the ongoing and completed works being carried out according to contract [2]. The payment to contractor and labour on time is important to maintain the project construction and minimize delays $[11,14]$. As money is one of the motivational factors to maintain the work progress. Furthermore, timely payment help contractor to finance the progress of construction in future [17]. [18, 22] suggested that the payment should be paid to other parties as agreed in contract on time to avoid the delay in the project. The late release of the amount to contractor cause work progress is a delay. Therefore, if the finance department releases all the payment to approved ADP project to engineering department's account instead of quarterly release the amount which takes more time to process the payment released [23] can avoid delay in construction by the contractor. The delay in construction project also can be explained via financial insecurities which always become major issues of the contractor to finance the project development in advance without payment from owners. Thus $[30,34]$ recommended that fast payment to the contractor will enable contractors to finance the project. It concludes that financial support to the contractor from owners is important to maintain the work progress according to the schedule and contract agreement. As payment on time also can motivated contractor and labours increase work performance in a construction project.

\subsection{Interpersonal}

Interpersonal has to be emphasized in the construction sector. As interpersonal relates to human resource management and development in a construction project. A good human resource management and development, contribute to minimizing delays in construction project. Based on Table 2, there are three major ideas of minimizing delays were suggested. 
Table 2. Minimizing Delay Items under Interpersonal Categories

\begin{tabular}{|l|}
\hline \multicolumn{1}{|c|}{ Items (Authors) } \\
\hline Hiring experienced personnel in the field of work and avoid choose low biding. $[2-4,9,14,18$, \\
$20,21,23,26,27,32,34-36,41-46]$ \\
\hline Avoiding delaying the response to contractor's queries and approval the submitted submittals \\
and shop drawings.[2, $4,17,26,34-36]$ \\
\hline Proper communication and coordination \\
{$[2,4,10,12,16,17,21-23,27,28,32,35,40,44]$} \\
\hline Training programs for their workers in order to update their knowledge \\
{$[3-5,11,13,14,16,17,19,28,29,33,38,45]$} \\
\hline Motivate the labor $[4,15,18,25,30]$ \\
\hline
\end{tabular}

Contractors should conduct training programs for their workers to update their knowledge and skills and that ideas are strongly agreed in $[5,9,11,19]$. Low technical and managerial skills of contractors are the problems which cause construction delays [19]. Thus, new knowledge and skill on technical work will fasten the construction works. It suggested for contractors to organize training programs for their workers to update their knowledge and improve their management skill. Every day, new technologies are being introduced into the construction sector, so that every individual from the related sector have to update themselves on the technologies to make the work smoother and in good quality. Thus, the continuous work-training programs for personnel in the industry is necessary to update their knowledge and be familiar with project management techniques and processes [11]. Lack of talent personnel can increase the project time and cost. It believed the shortage of specialist in project management, engineering, surveying, contract management and the skilled or semi-skilled labour due to education system often failed to deliver better manpower [9]. The advanced technology still questionable does not competent if knowledge of the worker is not updated to increase the work progress and quality of the constructions project. Thus, the manpower with advance knowledge and great skills in construction is the only way can avoid the delay issue. As the knowledgeable manpower able to demonstrate their knowledge and skills in managing proper construction works.

In construction management, a proper communication and coordination between main parties (owner, contractor, and consultant) need to build and well established. In [4], excellent communication relationship can enhance proper monitoring, coordination and increase the productivity of the project as pre-scheduled. Proper communication should be established between the parties [15]. Clear information and communication channels are effective methods to avoid construction [19]. The schedule delays and cost escalation can be avoided via effective communication between the owner, contractor and consultant [20]. Thus, the parties should focus on teambuilding communication to achieve the construction target time-frame. Also, the good coordination between parties able to increase production in construction project [30]. Proper communication between owner and contractor as they able to pre-planned project execution and reach for an agreement to avoid delays $[25,38]$. This idea agreed in [43], communication between internal parties can reduce construction delay as they able to discussion among them in details on the construction process. Excellent communications and good coordination are needs in both construction management and promote good relations with the owner, contractor, consultant and also employer to achieve construction targets.

Furthermore, hiring experienced personnel (constructor, consultant, and subcontractor) and avoid choose low biding. An inexperienced construction personnel and awarding the project to the lowest bide lead to construction delay as they unable to plan and schedule the process accordingly [27]. Construction delay can be avoided if constructors chosen for the project was their expertise field or they had gained experience in the previous project [26]. 
The owner needs to choose the contractor based on experience in previous construction project [41]. Appoint an experienced consultant to minimize the delay and avoid rework [18]. Constructor and consultant with reliable experience need to choose to minimize delay, and it safe to avoid using the traditional technique (choose based on the lowest bide) [9]. Owner requires doubling check the contractors submitted documents, quality's, and capabilities in conducting the project with their resources [21, 40]. A big construction project tends to appoint subcontractor. However, faced delay issue if the subcontractor chose is inexperienced and unreliable. Therefore, selection of subcontractor should have sufficient experience, good reputation and reliable as the construction project can complete within time $[2,18,33]$. The subcontractor should have the capability and reliability to conduct the construction as planned [22]. A better investigate the background (experience, financial and resources) of contractor, consultant, and subcontractor before awarding the project to lowest bid.

\subsection{Technical}

The technique and the way in which they are put together by the project management process are fundamental to achieving the client's objectives. They encompass evaluation, appraisal and control methods, contractual techniques and approaches to design, as well as the techniques for constructing the project [7]. Table 3, listed the main items in the technical element discussed below.

Table 3. Minimizing Delay Items under Technical Categories

\begin{tabular}{|l|}
\hline \multicolumn{1}{|c|}{ Items (Authors) } \\
\hline Inspection and testing by consultants in construction [26,35] \\
\hline Design documents should be approved promptly [26,35] \\
\hline Time allowed for developing the design is increased. [42] \\
\hline Select qualified designers to minimize potential claims. [42] \\
\hline Producing design documents should be on time as a mistake can be corrected soonest $[4,30,38]$ \\
\hline
\end{tabular}

Design can contribute to the major issue. Firstly, if the designs need to be completed on time, the consultant needs to provide a realistic design schedule for the designer to finish it on the time agreed. This can minimize the error in design. Furthermore, error in design needs to be addressed immediately so that any activity can proceed at site execution. This to avoid delay issue as the time taken to obtain new approval from the owner or agency might delay the construction project [4]. In [30], early production of design can ensure the project execution on the time to avoid delays. This gave time to design recheck and redone before the construction starts. Development of a good document system to identify the error in design and able to fix the error early to avoid last minutes approval that could cause the delay in construction projects [38]. Without a complete proper designing of the project construction on time, the actual site execution unable to be preceded accordingly which can delay the process of construction. As the design is very important, the design needs to be done within the agreed timeframe and flaws in design need to redone to avoid issue after construction because this may cause delay.

Document of design need approved in time to allow the implementation of a project. In this issue, the owner needs to be concerned. As sometimes, the time taken for the owner to approve the design documents might cause the delay. Thus, the owner should take a decision quickly and approved promptly to construction execution [22, 26]. As the inventor of the construction project, owners require being quick and prompt to approve documents also takes decisions to avoid delays. 
The inspection by the consultant in the site can maintain and increase a good work progress and also minimize delays in construction. Inception is necessary activates by the consultant to verify the quality of the construction project [26]. Consultant inception can testify the quality of the work in construction site [20]. The consultant can control the quality of the construction project and minimize delays of the construction project. Which, construction parties can avoid the rebuild or rework issue in future.

\subsection{Technology}

Technology in its broad meaning connotes the practical arts, bodies of skills, knowledge, and procedures or making, using and doing useful things. They are techniques: means for accomplishing recognized purpose [47]. In Table 4, two methods of minimizing the delay in the construction project were identified.

Table 4. Minimizing Delay Items under Technology Categories

\begin{tabular}{|l|}
\hline \multicolumn{1}{|c|}{ Items (Authors) } \\
\hline Uses of monitoring tools or software (Primavera and MSP) $[3,18,38]$ \\
\hline Building information modeling (BIM) [1,15,48-50] \\
\hline Productivity can be enhanced by using the modern equipment's $[4,11,24,32]$ \\
\hline
\end{tabular}

In $[1,15]$ the authors claim that the introduction of building information modelling (BIM) in the construction industry, could make a positive impact on minimizing delay in the construction industry. Building Information Modeling (BIM) can identify the fault of construction plan easily. As they can observe the construction project virtually in the $3 \mathrm{D}$ model [49]. Thus, contractor and consultant can redo the plan in an early stage of construction. This also reduces rework, minimize time and cost to complete the project construction. Furthermore, applied BIM in construction help contractor to plan and schedule and execute the project properly. Uses of BIM in construction will increase efficiency and quality of construction project [48].

Development of the advanced technology in the construction sector can minimize delays in construction project. Construction management should use modern electronic technology to monitoring tools and supervise the labour activity and productivity in sites $[3,18]$. Thus, the delay of construction can be minimized. The uses of construction software such as MPS and Primavera [36] can minimize delay. The software's especially, designed to assist project head or management team to manage labour, planning project construction (model), scheduling and monitoring the project construction. This can provide excellent quality work and finish the project on time as per agreed in the contract.

The contractor should depend on advanced technology equipment which suitable and well repaired in construction work [4, 24]. As the suitable and adequate equipment ensure minimization of delay in construction project [32]. Utilization of modern equipment enhances the productivity of the construction project. Modern equipment does not only replace human power but also reduce site accidents. The site accident also the factor cause delays in construction project. Thus, the adaption of modern equipment's can increase the safety of the worker and reduce site accident. On other hands, the productivity boost and the construction finish within the time [11]. Modern technologies contribute in minimize delay in the construction project as work can be done faster with computer-aided to reduce mistakes. 


\section{Conclusions}

Delay issue is an ongoing issue faced by construction industries for decades. However, the delays issue can be minimized via proper management, interpersonal, technical and technology in conduct construction project. The construction parties can focus on the element to identify issues and applied the ideas to minimize delay. Management provides an idea to manage a construction project in time, control, and financial management. While interpersonal, establish a good communication relationship, produce skilled labour and hire a competent contractor to conduct a project. Furthermore, technical ensure a quality of the construction project. Besides, technology enhances productivity via modern tools and software. Thus, delays in construction can be minimized. Future studies will focus to build a model of minimizing delay in construction that can be applied in construction or government project and to be implemented in policymaking.

This research supported by the Ministry of Higher Education using research funds of Fundamental Research Grants Scheme FRGS/1/2017/SS03/UKM/03/1. We thank our colleagues from Universiti Kebangsaan Malaysia (UKM), who provided insight and expertise that greatly assisted the research.

\section{Reference}

1. S. D. Berlinda Lessing, Derek Thurnell, "Main Factors Causing Delays in Large Construction Projects: Evidence from New Zealand," J. Manag. Econ. Ind. Organ., vol. Vol.1 No.2, no. August, p. pp.63-82, 2017.

2. M. M. Marzouk and T. I. El-Rasas, "Analyzing delay causes in egyptian construction projects," J. Adv. Res., vol. 5, no. 1, pp. 49-55, 2014.

3. S. Durdyev, M. Omarov, and S. Ismail, "Causes of delay in residential construction projects in Cambodia," Cogent Eng., vol. 4, no. 1, pp. 1-12, 2017.

4. F. Elharare, A. Elhaniash, and S. Stevovic, "Towards factors affecting delays in construction projects : A case of Libya," vol. 2, no. 1, pp. 2013-2016, 2016.

5. A. S. Faridi and S. M. El-Sayegh, "Significant factors causing delay in the UAE construction industry," Constr. Manag. Econ.,vol. 24, no. 11, pp. 1167-1176, 2006.

6. "Statistik Projek-Projek Perumahan Swasta Mengikut Kategori Sehingga 30 April 2018," no. April, p. 2018, 2018.

7. M. F. N. and B. J. F. Trauner, T. J., W. A. Manginelli, J. S. Lowe, Construction Delays: Understanding Them Clearly, Analyzing Them Correctly. 2009.

8. A. Walker, Project Management In Construction, 2015.

9. W. Koshe and K. N. Jha, "Investigating Causes of Construction Delay in Ethiopian Construction Industries," J. Civil, Constr. Environ. Eng.,vol. 1, no. 1, pp. 18-29, 2016.

10. G. X. Chen, M. Shan, A. P. C. Chan, X. Liu, and Y. Q. Zhao, "Investigating the causes of delay in grain bin construction projects: the case of China," Int. J. Constr. Manag., vol. 3599, no. August, pp. 1-14, 2017.

11. M. K. Sha, P. B. Shahi, R. Pandit, and A. Pandey, "Causes and Effects of Delays in Constrution Projets," IOSR J. Mech. Civ. Eng., vol. 14, no. 2, pp. 52-58, 2017.

12. A. A. Salunkhe, "Identification of critical construction delay factors Identification of Critical Construction Delay Factors," no. April 2014, 2018.

13. M. M. Atout, "Delays Caused by Project Consultants and Designers in Construction Projects," Int. J. Struct. Civ. Eng. Res., vol. 5, no. 2, 2016.

14. R. A. Khan and W. Gul, "Emperical study of critical risk factors causing delays in 
construction projects," Proc. 2017 IEEE 9th Int. Conf. Intell. Data Acquis. Adv. Comput. Syst. Technol. Appl. IDAACS 2017, vol. 2, pp. 900-906, 2017.

15. R. K. Shah, "An Exploration of Causes for Delay and Cost Overruns In Construction Projects: Case Study of Australia, Malaysia \&amp; Ghana," J. Adv. Coll. Eng. Manag., vol. 2, no. July, p. 41, 2016.

16. S. P. Wanjari and G. Dobariya, "Identifying factors causing cost overrun of the construction projects in India," Sadhana - Acad. Proc. Eng. Sci., vol. 41, no. 6, pp. 679-693, 2016.

17. M. Kesavan, N. N. Gobidan, and P. B. G. Dissanayake, "Planning \& mitigation methods to reduce the project delays in Sri Lankan civil engineering construction industries," no. 12, pp. 102-107, 2015.

18. O. J. Emeka, "Causes of delay in large construction project in Nigeria construction industry," Uclan Univercity of Central Lancashire, 2016.

19. Kang Sik Wei, "Causes, effects and methods of minimizing delays in construction projects," Univ. Teknol. Malaysia, 2010.

20. C. Kaliba, M. Muya, and K. Mumba, "Cost escalation and schedule delays in road construction projects in Zambia," Int. J. Proj. Manag., vol. 27, no. 5, pp. 522-531, 2009.

21. P. A. Koushki, K. Al-Rashid, and N. Kartam, "Delays and cost increases in the construction of private residential projects in Kuwait," Constr. Manag. Econ., vol. 23, no. 3, pp. 285-294, 2005.

22. R. F. Aziz, "Ranking of Delay Factor in Construction Projects After Egyption Revolution," Alexandria Eng. J., vol. 52, no. 3, pp. 387-406, 2013.

23. S. Hussain, F. Zhu, Z. Ali, H. Aslam, and A. Hussain, "Critical Delaying Factors: Public Sector Building Projects in Gilgit-Baltistan, Pakistan," Buildings, vol. 8, no. 1 , p. $6,2018$.

24. R. Divya and S. Ramya, "Causes, Effects And Method Of Minimizing Delays In Construction Projects," Natl. Conf. Res. Adv. Commun. Comput. Electr. Sci. Struct., pp. 47-53, 2015.

25. M. A. Othuman Mydin, N. M. Sani, M. Taib, and N. Mohd Alias, "Imperative Causes of Delays in Construction Projects from Developers' Outlook," MATEC Web Conf., vol. 10, p. 6005, 2014.

26. M. Gündüz, Y. Nielsen, and M. Özdemir, "Quantification of Delay Factors Using the Relative Importance Index Method for Construction Projects in Turkey," $J$. Manag. Eng., vol. 29, no. 2, pp. 133-139, 2012.

27. R. A. Khan, U. Gazder, and A. Qayoom, "International Journal of Advanced and Applied Sciences Comparison of delay factors and remedies ' rankings for building construction projects in developing countries," vol. 4, no. 4, pp. 33-42, 2017.

28. A. Boru, "Determinants of Delay and Cost Overruns in Kenya' S Public Sector Construction Projects: A Case of Meru County, Kenya. Adano Boru a Research Project Submitted In Partial Fulfillment of the Requirements for the Award of the Degree of Master of Arts In," 2016.

29. B. JR, M. JM, H. ROTHBART, and H. RB, "Causes of delay in the construction industry," ASCE J Constr Div, vol. 97, no. CO2, pp. 177-187, 2016.

30. N. Al-Emad, I. Abdul Rahman, S. Nagapan, and Y. Gamil, "Ranking of Delay Factors for Makkah's Construction Industry," MATEC Web Conf., vol. 103, p. 3001, 2017.

31. R. Apolot, H. Alinaitwe, and D. Tindiwensi, "An Investigation into the Causes of Delay and Cost Overrun in Uganda's Public Sector Construction Projects," Second Int. Conf., pp. 305-312, 2011. 
32. K. Khair, Z. Mohamed, R. Mohammad, H. Farouk, and M. E. Ahmed, "A Management Framework to Reduce Delays in Road Construction Projects in Sudan,” Arab. J. Sci. Eng., vol. 43, no. 4, pp. 1925-1940, 2018.

33. R. Assefa, "School of Graduate Studies Schedule Delay Identification and Assessment on Addis Ababa' S Light Rail Transit Construction," 2015.

34. S. A. Assaf and S. Al-Hejji, "Causes of delay in large construction projects," Int. J. Proj. Manag., vol. 24, no. 4, pp. 349-357, 2006.

35. R. F. Aziz and A. A. Abdel-Hakam, "Exploring delay causes of road construction projects in Egypt," Alexandria Eng. J., vol. 55, no. 2, pp. 1515-1539, 2016.

36. M. Rafieizonooz, M. R. Salim, E. Khankhaje, M. Warid Hussin, A. Zarebidaki, and Salmiati, "Determining the Causes of Delay by Using Factor Analysis in Tehran's Construction Projects," Appl. Mech. Mater., vol. 735, no. October, pp. 109-116, 2015.

37. E. Science, "Mitigating delay and non-payment in the Malaysian construction industry Mitigating delay and non-payment in the Malaysian construction industry," pp. 0-6, 2018.

38. A. A. Salunkhe and R. S. Patil,"Effect of Construction Delays on Project Time Overrun: Indian Scenario,”Int. J. Res. Eng. Technol.,vol.3,no.1, pp. 543-547, 2014.

39. M. M. Amandin and J. W. Kule, "Project Delays on Cost Overrun Risks: A Study of Gasabo District Construction Projects Kigali, Rwanda," J. Adv. Res., vol. 5, no. 1, pp. 21-34, 2016.

40. D. M. Matin, "Identifying The Effective Factors for Cost Overrun and Time Delay inWater Construction Projects," Eng. Technol. Appl. Sci. Res., vol. 6, no. 4, pp. 1062-1066, 2016.

41. S. Y. Kim, K. N. Tuan, and V. T. Luu, "Delay factor analysis for hospital projects in Vietnam," KSCE J. Civ. Eng., vol. 20, no. 2, pp. 519-529, 2016.

42. M. Mishmish and S. M. El-Sayegh, "Causes of claims in road construction projects in the UAE," Int. J. Constr. Manag., vol. 18, no. 1, pp. 26-33, 2018.

43. Y. C. Kog and D. Ph, "Project Management and Delay Factors of Public Housing Construction," vol. 23, no. 1, 2018.

44. D. M. Matin, "Identifying The Effective Factors for Cost Overrun and Time Delay in $\backslash n W a t e r$ Construction Projects," Eng. Technol. Appl. Sci. Res., vol. 6, no. 4, pp. 1062-1066, 2016.

45. M. B. I. Mohamed, "a Study of Project Delay in Sudan," 2015.

46. R. F. Aziz, Ranking of delay factors in construction projects after Egyptian revolution, vol. 52, no. 3. Faculty of Engineering, Alexandria University, 2013.

47. D. Gabbay, P. Thagard, and J. Woods, Philosophy of Technology and Engineering Sciences. 2009.

48. M. M. Tahir, N. A. Haron, A. H. Alias, A. N. Harun, I. B. Muhammad, and D. L. Baba, "Improving cost and time control in construction using building information model (Bim): A review," Pertanika J. Sci. Technol.,vol. 26, no. 1, pp. 21-36, 2018.

49. S. Shujaa, S. Gardezi, U. Teknologi, N. Shafiq, and U. Teknologi, "Prospects of Building Information Modeling ( BIM ) in Malaysian Construction Industry as Conflict Resolution Tool Prospects of Building Information Modeling (BIM) in Malaysian Construction Industry as Conflict Resolution Tool," 2013.

50. Z. A. Essa Alenazi, "Building Information Modelling for Construction Delay Management," world Acad. Sci. Eng. Technol. Int. J. Ciil Environ. Eng., vol. 11, no. 6, pp. 823-834, 2017. 